\title{
PERSENTASE TOTAL AKTIVITAS ANTIOKSIDAN \\ DARK CHOCOLATE DAN MILK CHOCOLATE SECARA SPEKTROFOTOMETRI
}

\author{
Lany Nurhayati, Supriyono E. Wardoyo dan Rika Rosita \\ FMIPA Universitas Nusa Bangsa \\ Jl. KH. Sholeh Iskandar Km. 4, Tanah Sareal, Bogor \\ email : lanyhikmat@yahoo.com
}

\section{ABSTRACT \\ Percentage Total Activities of Antioxidant of Dark Chocolate and Milk Chocolate Using Spectrofotometric}

\begin{abstract}
Chocolate is loaded with various properties, one of them as an antioxidant because it contains katetin, polyphenols, flavonoids that can prevent premature aging. The content of antioxidants in chocolate was varied, dark chocolate (DC) of at least $70 \%$, while milk chocolate $(M C)$ is was lower. The compound of 1,1-diphenyl-2picrylhydrazyl (DPPH) was a stable free radical compounds that would neutralize each other if treated with antioxidant compound. Percentage of total activity was calculated by the reaction between DPPH compounds and chocolate spectrophotometrically at $\lambda$ 520nm. The results showed that the DC brand A was 59.19\%, 17 : brand $B 16 \%$ and brand $C 8.80 \%$, while the $M C$ was $11,07 \%$ brand $A$, brand $B$ 7, $00 \%$ and brands $C 5.84 \%$. Comparison of DC percentages was higher than MC because the DC contains catechins, riboflavon, vitamin $E$ and vitamin $C$ or minerals $\mathrm{Mg}$ and $\mathrm{Cu}$ that reacted with $\mathrm{DPPH}$, so that DC could be used as one source of antioxidants.
\end{abstract}

Keywords : antioxidants, dark chocolate, milk chocolate, DPPH .

\begin{abstract}
ABSTRAK
Cokelat sarat dengan berbagai macam khasiat, salah satunya sebagai antioksidan karena mengadung katetin, polifenol, flavonoid yang dapat mencegah penuaan dini. Kandungan antioksidan dalam coklat bervariasi Dark chocolate (DC) minimal 70\% sedangkan Milk chocolate $(M C)$ lebih rendah. Senyawa 1,1-diphenyl-2picrylhydrazyl (DPPH) merupakan senyawa radikal bebas stabil yang akan saling menetralkan jika direaksikan dengan senyawaan antioksidan. Persentase total aktifitas dihitung melalui reaksi antara senyawa DPPH dengan cokelat secara spektrofotometri pada $\lambda$ 520nm. Hasil penelitian menunjukkan bahwa $D C$ merk A sebesar 59.19\%, merk B $17.16 \%$, dan merk C $8.80 \%$, sedangkan $M C$ merk A sebesar $11.07 \%$, merk B $7.00 \%$, dan merk C $5.84 \%$. Perbandingan persentase $D C$ lebih tinggi dibanding $M C$ karena $D C$ mengandung katekin, riboflavon, vitamin $\mathrm{E}$, dan vitamin $\mathrm{C}$, serta mineral $\mathrm{Mg}$ dan $\mathrm{Cu}$ yang berekasi dengan $\mathrm{DPPH}$, sehingga $D C$ dapat dijadikan sebagai salah satu sumber antioksidan.
\end{abstract}

Kata kunci : antioksidan, dark chocolate, milk chocolate, DPPH.

\section{PENDAHULUAN}

Cokelat terkenal sebagai makanan lezat yang dicintai banyak orang. Di balik kenikmatan yang diberikan dan sensasi unik yang ditimbulkan setelah kita mengonsumsi cokelat, ternyata cokelat sarat dengan berbagai macam khasiat. Salah satunya adalah sebagai antioksidan. Cokelat merupakan pohon yang dapat tumbuh baik di daerah panas, mengandung biji seperti kacang - kacangan antara 50 -
100 biji. Biji - biji ini diolah menjadi bubuk atau kristal cokelat untuk dibuat makanan atau minuman (Tim Bina Karya Tani, 2008).

Cokelat memiliki kandungan antioksidan sehingga cokelat menjadi salah satu makanan atau minuman kesehatan. Selain itu bermanfaat untuk kecantikan, karena antioksidan seperti katekin, polifenol, flavonoid, yang ada di dalamnya dapat mencegah penuaan dini, maka tidak 
heran bila saat ini berkembang lulur cokelat yang sangat baik untuk kecantikan kulit (Astawan, 2009).

Kandungan antioksidan bervariasi pada setiap cokelat, bergantung pada berbagai faktor, diantaranya kandungan cokelat dan proses pengolahannya. Dark Chocolate sebagai salah satu jenis cokelat memiliki kandungan cacao yang paling tinggi yaitu paling sedikit $70 \%$. Sedangkan, milk chocolate atau cokelat susu merupa kan campuran cacao dengan susu dan gula, sehingga kandungan cokelatnya tidak sebanyak pada dark chocolate (Sofia, 2005).

Antioksidan adalah substansi yang diperlukan tubuh untuk menetralisir radikal bebas sehingga dapat mencegah kerusakan yang ditimbulkan oleh radikal bebas terhadap sel normal, protein dan lemak. Antioksidan menstabilkan radikal bebas dengan melengkapi kekurangan elektron yang dimiliki radikal bebas. Ada beberapa bentuk antioksidan, di antaranya vitamin, mineral, dan fitokimia. Berbagai tipe antioksidan tersebut bekerja bersama dalam melindungi sel normal dengan cara menetralisir radikal bebas (Brotodjojo, 2008).

$\begin{array}{cr}\text { Senyawa } & \text { 1,1-diphenyl-2- } \\ \text { picrylhydrazyl } & \text { (DPPH) }\end{array}$
senyawa radikal bebas stabil yang akan saling menetralkan jika direaksikan dengan senyawaan antioksidan, dengan merubah warna ungu menjadi kuning karena antioksidan memberikan elektronnya pada DPPH. Uji aktivitas antioksidan dilakukan melalui reaksi peredaman radikal DPPH. Uji DPPH ini merupakan metode yang mudah untuk menapis sejumlah kecil molekul antioksidan, karena reaksi dapat diamati intensitas antioksidannya melalui spektrofotometri sederhana (Yuhernita dan Juniarti, 2011). Hasil penelitian yang dilakukan oleh Liempah tahun 2008, membuktikan bahwa senyawa antioksidan berupa propolis dalam madu lebah dapat saling menetralkan ketika direaksikan dengan radikal bebas DPPH. Namun dari hasil penelitian tersebut tidak diungkapkan persentase total aktifitasnya, sehingga perlu dilakukan penelitian lanjutan dengan menggunakan bahan antioksidan lain seperti cokelat. Antioksidan dalam cokelat pun akan saling menetralkan jika direaksi kan dengan DPPH. Hal inilah yang menjadi dasar pada penelitian ini, sehingga persentase total aktifitas antioksidan dalam cokelat pun dapat ditetapkan melalui reaksi antara senyawa DPPH dengan cokelat itu sendiri secara spektrofotometri.

Penelitian ini bertujuan mengetahui perbandingan persentase total aktifitas antioksidan dark chocolate dan milk chocolate.

\section{BAHAN DAN ALAT}

\section{Bahan}

Bahan yang digunakan dalam penelitian ini adalah cokelat siap konsumsi (dark chocolate dan milk chocolate dari 3 merk berbeda) yang dijual bebas di toko toko dan pasar, etanol (96 \%), 1,1diphenyl-2-picrylhydrazyl (DPPH) dan Asam askorbat (working standard, batch no.806009, kemurnian : $99.40 \%$, tanggal kadaluarsa : 23 Februari 2010, suhu penyimpanan $2-8^{\circ} \mathrm{C}$ ).

Sampel yang digunakan berasal dari 3 merk berbeda, masing - masing merk tersebut terdiri dari dua jenis, yaitu dark chocolate dan milk chocolate. Merk A merupakan sampel cokelat yang di dalamnya terdapat bahan tambahan madu dan kacang almon. Merk B merupakan sampel cokelat yang di dalamnya terdapat bahan tambahan kacang mete. Sedangkan merk C merupakan sampel cokelat yang tidak terdapat madu, kacang almon maupun kacang mete sebagai bahan tambahan.

\section{Alat}

Alat yang digunakan dalam penelitian ini antara lain : neraca analitik, labu ukur, piala gelas, pipet volumetrik, kertas karbon, ultrasonic, penyaring 0,45 $\mu \mathrm{m}$, labu semprot, 8453 .

\section{METODE PENELITIAN}

Penelitian ini menggunakan metode eksperimental, terdiri dari empat tahap, yaitu : 


\section{Preparasi Sampel}

- Sampel Dark Chocolate

Sejumlah sampel dark chocolate ditimbang \pm 1.00 gram dengan teliti menggunakan neraca analitik, dimasukkan ke dalam labu ukur $100 \mathrm{~mL}$, dilarutkan dengan etanol $96 \%$, diultrasonic selama \pm 15 menit, sampai semua sampel larut, didiamkan sampai tercapai suhu ruang, diimpitkan dengan etanol, dihomogenkan kemudian disaring menggunakan penyaring $0,45 \mu \mathrm{m}$. Larutan hasil saringan dipipet $4 \mathrm{~mL}$ dimasukkan ke dalam labu ukur 20mL, diencerkan dan diimpitkan dengan etanol $96 \%$, dihomogenkan (konsentrasi sample $2 \times 10^{-3} \mathrm{mg} / \mathrm{mL}$ ). Larutan tersebut dipipet $2 \mathrm{~mL}$ dimasukkan ke dalam tabung reaksi bertutup yang telah dilapisi dengan kertas karbon dan telah berisi $2 \mathrm{~mL}$ larutan DPPH (konsentrasi larutan DPPH yang $\begin{array}{lllll}\text { dipakai } 5 & \text { x } & 10^{-2} & \mathrm{mg} / \mathrm{mL}) \text {, }\end{array}$ dihomogenkan, kemudian di diamkan selama \pm 30 menit. Diukur absorbans sampel (A spl) menggunakan spektrofotometer UV - VIS Agilent 8453 di $\lambda$ maksimum dengan etanol sebagai blanko.

\section{- Sampel Milk Chocolate}

Pengerjaan sampel milk chocolate sama dengan sampel dark chocolate.

- Larutan kontrol terdiri dari $2 \mathrm{~mL}$ larutan DPPH dengan konsentrasi $5 \times 10^{-2} \mathrm{mg} / \mathrm{mL}$ ditambah $2 \mathrm{~mL}$ etanol $96 \%$, yang direaksikan dalam tabung reaksi bertutup dan telah dilapisi oleh kertas karbon. Setelah dihomogen kan, didiamkan selama \pm 30 menit, kemudian diukur absorbansnya (A ctrl) menggunakan spektrofotometer
UV - VIS Agilent 8453 di $\lambda$ maksimum.

- Sebagai pembanding, ditetapkan juga persentase total aktifitas antioksidan terhadap asam askorbat. Tahapan kerja yang dilakukan sama dengan tahapan kerja pada sampel cokelat, baik dark chocolate maupun milk chocolate.

- Semua tahapan preparasi sampel dilakukan secara triplo dan dilakukan di ruang gelap (ruang preparasi dengan pencahayaan lampu neon yang diberi cat berwarna kuning gelap). Semua labu ukur yang dipakai adalah labu ukur berwarna coklat (amber glass) dan dilapisi kertas karbon dibagian luarnya.

\section{Penetapan $\lambda$ (panjang gelombang) maksimum :}

Spektrum dibuat dari larutan standard DPPH dalam etanol $96 \%$, antara panjang gelombang $(\lambda) 400-900 \mathrm{~nm}$, sehingga didapatkan absorbans maksimum pada $\lambda$ tertentu.

\section{Kurva standard DPPH :}

DPPH ditimbang $\pm 5.00 \mathrm{mg}$, dimasukkan ke dalam labu ukur $50 \mathrm{~mL}$ yang telah dilapisi kertas karbon, dilarutkan dan diimpitkan sampai tanda garis dengan etanol $96 \%$, kemudian dihomogenkan. Pengenceran dibuat serial dengan beberapa konsentrasi, yaitu memipet larutan tersebut $2 \mathrm{~mL}, 3 \mathrm{~mL}, 4 \mathrm{~mL}$, $5 \mathrm{~mL}$ dan $6 \mathrm{~mL}$ ke dalam masing - masing labu ukur $20 \mathrm{~mL}$ yang telah dilapisi oleh kertas karbon, kemudian diencerkan dan diimpitkan dengan etanol $96 \%$, dihomogenkan. Sehingga didapat deret konsentrasi larutan standard $1 \times 10^{-2}$ $\mathrm{mg} / \mathrm{mL}, 1.5 \times 10^{2} \mathrm{mg} / \mathrm{mL}, 2 \times 10^{-2} \mathrm{mg} / \mathrm{mL}$, $2.5 \times 10^{-2} \mathrm{mg} / \mathrm{mL}$ dan $3 \times 10^{-2} \mathrm{mg} / \mathrm{mL}$. Selanjutnya, diukur absorbans deret larutan standard tersebut pada $\lambda$ maksimum yang telah didapat. 


\section{Penentuan waktu reaksi optimum :}

Asam askorbat ditimbang \pm 60.00 mg, kemudian dimasukkan ke dalam labu ukur $100 \mathrm{~mL}$, dilarutkan dengan etanol $96 \%$, diultrasonic selama \pm 15 menit, sampai larut sempurna, didiamkan sampai tercapai suhu ruang, diimpitkan dengan etanol. Selanjutnya, dipipet $5 \mathrm{~mL}$ larutan tersebut, dimasukkan ke dalam labu ukur $50 \mathrm{~mL}$, diencerkan dan diimpitkan dengan etanol $96 \%$, dihomogenkan. Kemudian, 2 $\mathrm{mL}$ larutan tersebut dipipet, dimasukkan ke dalam labu ukur $20 \mathrm{~mL}$, diencerkan dan diimpitkan dengan etanol $96 \%$, dihomogenkan (konsentrasi larutan 6 x 10 $0^{-3}$ $\mathrm{mg} / \mathrm{ml}$ ). Larutan tersebut dipipet $2 \mathrm{~mL}$ sebanyak empat kali, dimasukkan masing masing ke dalam empat tabung reaksi bertutup yang telah dilapisi oleh kertas karbon dan telah berisi $2 \mathrm{~mL}$ larutan DPPH dalam etanol $96 \%$ (konsentrasi larutan DPPH yang dipakai $5 \times 10^{-2} \mathrm{mg} / \mathrm{mL}$ ), dihomogenkan dan didiamkan dalam ruang gelap, kemudian setiap 10 menit sekali (10, 20, 30 dan 40 menit) diambil satu tabung tersebut, diukur absorbansinya mengguna kan spektrofotometer UV - VIS Agilent 8453 di $\lambda$ maksimum.

\section{HASIL DAN PEMBAHASAN}

\section{A. Panjang gelombang $(\lambda)$ maksimum}

Berdasarkan hasil scanning yang telah dilakukan terhadap larutan standard 1,1-diphenyl-2-picrylhydrazyl (DPPH) dalam etanol $96 \%$, antara $\lambda 400-900 \mathrm{~nm}$, didapatkan absorbans maksimum pada $\lambda$ $518 \mathrm{~nm}$ (Gambar 1), spektrum dari hasil pengukuran menggunakan spektrofoto meter UV - VIS Agilent 8453.

Hasil pengukuran $\lambda$ maksimum DPPH dapat berbeda pada beberapa penelitian. Pada penelitian ini, diperoleh $518 \mathrm{~nm}$, menggunakan pelarut etanol $96 \%$, labu ukur berwarna coklat yang dilapisi dengan kertas karbon dan melakukan tahapan analisis dalam ruang gelap. Kondisi ruang mempengaruhi hasil pengukuran, karena ruang yang gelap akan meminimal kan reaksi oksidasi DPPH oleh cahaya, begitu juga dengan pemakaian labu ukur berwarna coklat dan dilapisi oleh kertas karbon, sehingga akan diperoleh kestabilan pengukuran DPPH. Kurva absorbansi sampelpun menghasilkan bentuk spektrum yang sama dengan kurva absorbansi larutan DPPH. Sedangkan, penelitian yang dilaku kan pada uji aktifitas antioksidan propolis lebah madu yang dilakukan oleh Liempah (2008), $\lambda$ maksimum yang didapatkan adalah $520 \mathrm{~nm}$, pelarut yang digunakan etanol 96\%, dengan labu ukur yang digunakan tidak berwarna dan hanya dilapisi dengan aluminium foil. Kuncahyo (2007), uji aktifitas antioksidan ekstrak belimbing wuluh $\lambda$ maksimum yang didapatkan adalah $517 \mathrm{~nm}$, pelarut yang digunakan metanol dan eter. Ketidakstabilan ini disebabkan perbedaan penggunaan pelarut, kondisi ruang dan perangkat analisisnya.

\section{B. Perhitungan Aktifitas Antioksidan :}

Nilai Aktifitas Antioksidan sampel dapat dihitung melalui rumus berikut ini :

$$
A A(\%)=\frac{100-(A \operatorname{spl} x 100)}{A \operatorname{ctrl}}
$$

Keterangan :

AA(\%) : Nilai Aktifitas Antioksidan (\%)

A spl : Absorbans larutan sampel (dark chocolate atau milk chocolate dalam etanol $96 \%$ yang direaksikan dengan larutan DPPH dalam etanol $96 \%)$.

A ctrl : Absorbans larutan standard 1,1-diphenyl-2-picrylhydrazyl (DPPH) dengan konsentrasi $5 \times 10^{2} \mathrm{mg} / \mathrm{mL}$ ditambah $2 \mathrm{~mL}$ etanol $96 \%$

\section{Kurva kalibrasi larutan standard}

Deret larutan standard yang terdiri dari 5 titik konsentrasi $\left(1 \times 10^{-2} \mathrm{mg} / \mathrm{ml} ; 1.5\right.$ x $10^{2} \mathrm{mg} / \mathrm{ml} ; 2 \times 10^{-2} \mathrm{mg} / \mathrm{ml} ; 2.5 \times 10^{-}$ ${ }^{2} \mathrm{mg} / \mathrm{ml}$ dan $3 \times 10^{-2} \mathrm{mg} / \mathrm{ml}$ ) memberikan 
hasil berupa garis linier dengan persamaan garis $\mathrm{Y}=27,593 \mathrm{x}+0,001$ dan $\mathrm{R}^{2}=0,9999$ (Gambar 2).
Hasil pengukuran tersebut membuktikan bahwa DPPH merupakan radikal bebas stabil pada berbagai konsentrasi.

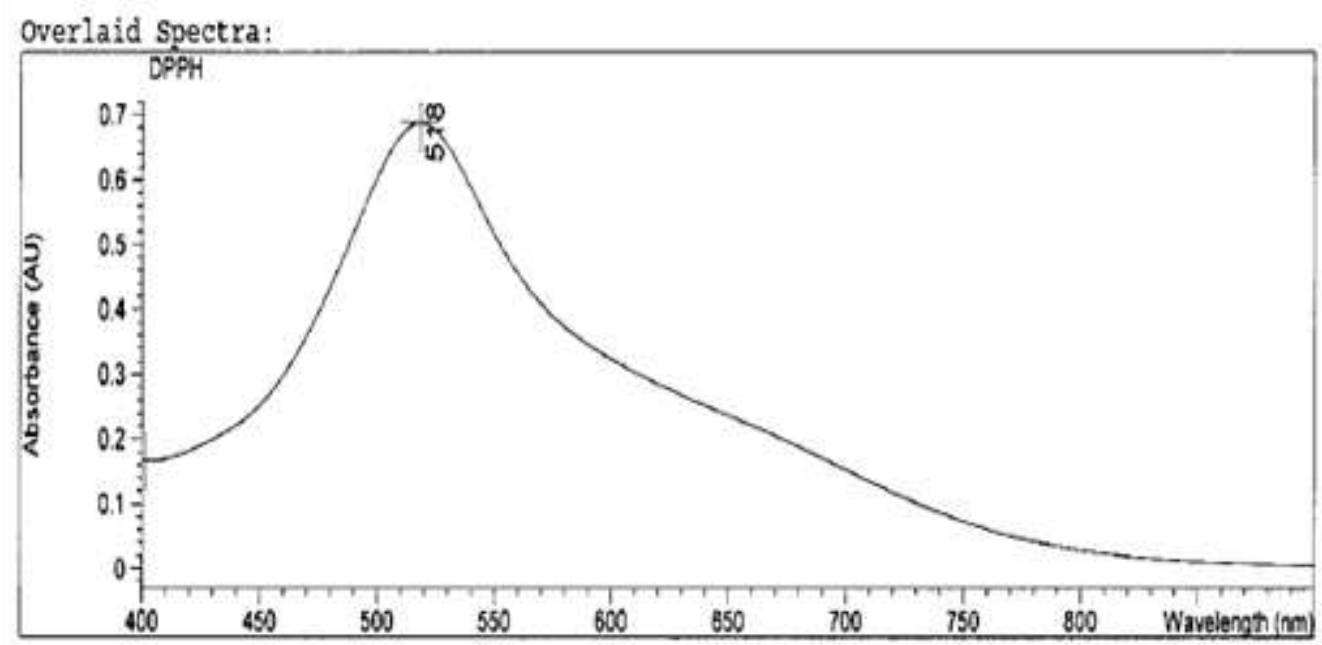

\begin{tabular}{|c|c|c|c|c|}
\hline Naze & Peaks (nm) & $\mathrm{Abs}(\mathrm{AU})$ & Valleys (nn) & $\operatorname{Abs}(\mathrm{AD})$ \\
\hline DPPF & 518.0 & 0.68673 & 402.0 & 0.16607 \\
\hline
\end{tabular}

Gambar 1. Spektrum Larutan DPPH dalam Etanol $96 \%$

\section{Kurva Kalibrasi Larutan Standard DPPH}

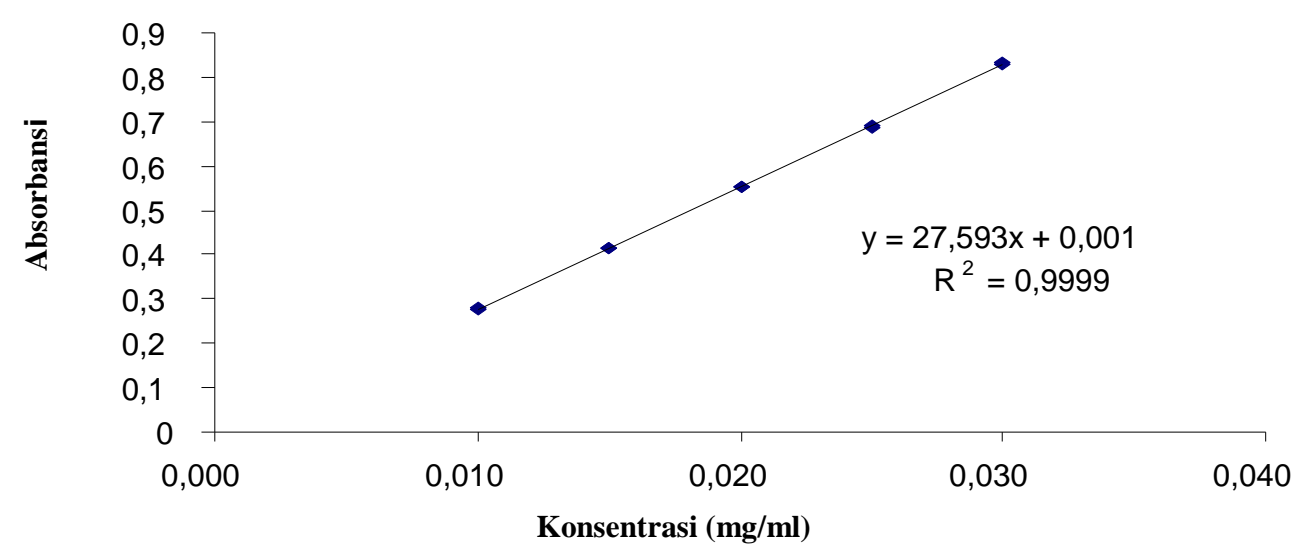

Gambar 2. Kurva kalibrasi larutan standard DPP 


\section{Waktu reaksi optimum}

Pengukuran waktu reaksi optimum dilakukan terhadap reaksi antara DPPH dengan salah satu antioksidan yang telah diketahui kemurniannya secara pasti, yaitu Asam askorbat. Hasil pengukuran tersebut mendapatkan waktu reaksi optimum pada menit ke 30 (Gambar 3).

Hasil pengukuran tersebut ditandai dengan tidak adanya penurunan yang signifikan antara besarnya absorbans yang dihasilkan pada pengukuran menit ke 20 dengan menit ke 30 .

\section{E. Persentase total aktifitas antioksidan pada beberapa jenis dan merk cokelat}

Penelitian terhadap persentase total aktifitas antioksidan pada beberapa jenis dan merk cokelat menghasilkan kandungan yang bervariasi (Gambar 4).

Hasil penelitian terhadap persentase total aktifitas antioksidan pada beberapa jenis dan merk cokelat didapatkan hasil terbesar pada sampel dark chocolate merk A, yaitu sebesar $59.19 \%$. Sampel merk A merupakan sampel cokelat yang di dalamnya terdapat bahan tambahan madu dan kacang almon. Madu dan kacang-kacangan termasuk bahan makanan yang banyak mengandung antioksidan, sehingga antioksidan yang terdapat dalam sampel merk A tidak hanya berasal dari katekin dan antioksidan lain dalam cokelat itu sendiri, tapi madu dan kacang almon yang terdapat di dalamnya juga memberikan aktifitas antioksidan. Semua jenis madu mengandung antioksidan, seperti vitamin $\mathrm{E}$ dan vitamin C. Sedangkan kacang almon mengandung riboflavin dan vitamin $\mathrm{E}$ yang sangat tinggi (Joseph, 2008).

Hasil persentase total aktifitas antioksidan pada sampel merk B menempati urutan kedua, dengan hasil pada dark chocolate sebesar $17.16 \%$. Sampel B merupakan sampel cokelat yang di dalamnya terdapat bahan tambahan kacang mete. Kacang mete berisi banyak magnesium dan tembaga (Joseph, 2008). Magnesium dan tembaga merupakan mineral - mineral yang termasuk dalam antioksidan, sehingga aktifitas antioksidan yang dihasilkan pada sampel merk B tidak hanya berasal dari katekin dan antioksidan lain dalam cokelat itu sendiri, tapi magnesium dan tembaga yang terkandung dalam kacang mete pun ternyata memberikan aktifitas antioksidan. Reaksi antara DPPH dengan antioksidan katekin, riboflavin, vitamin $\mathrm{E}$ dan vitamin $\mathrm{C}$ maupun dengan mineral magnesium $(\mathrm{Mg})$ dan tembaga $(\mathrm{Cu})(\mathrm{Gambar} 5)$.

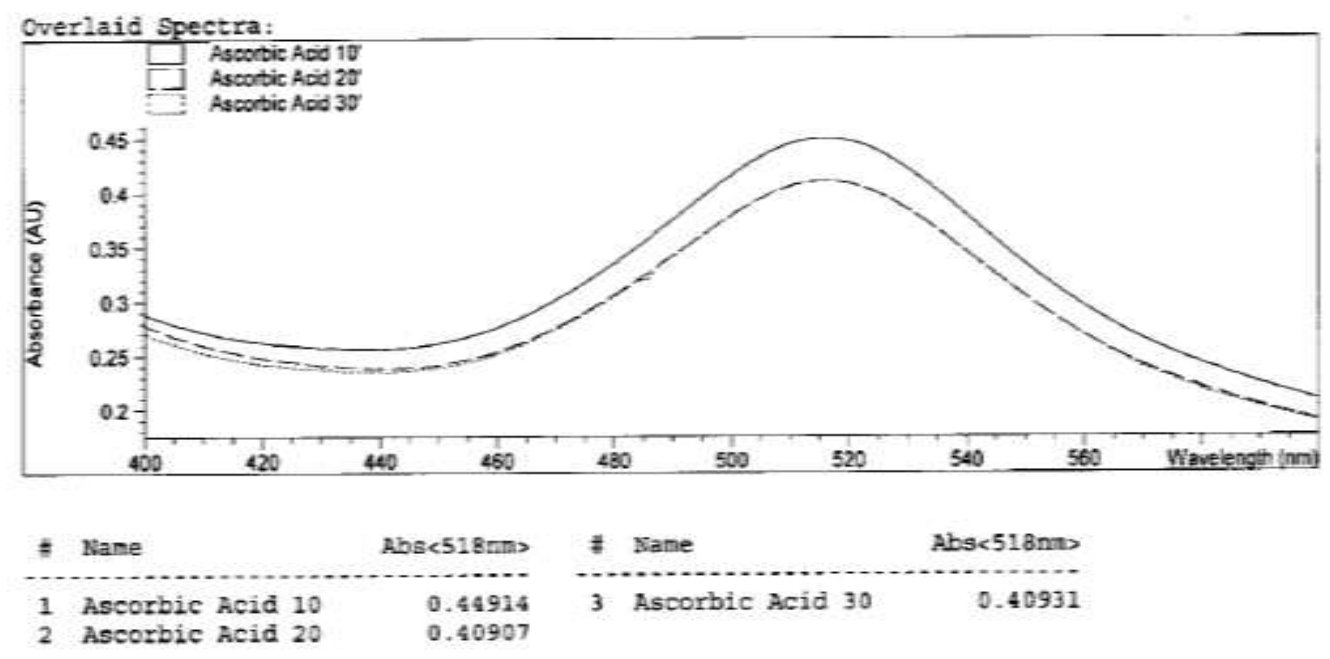

Gambar 3. Waktu reaksi optimum antara DPPH dengan Asam askorbat 


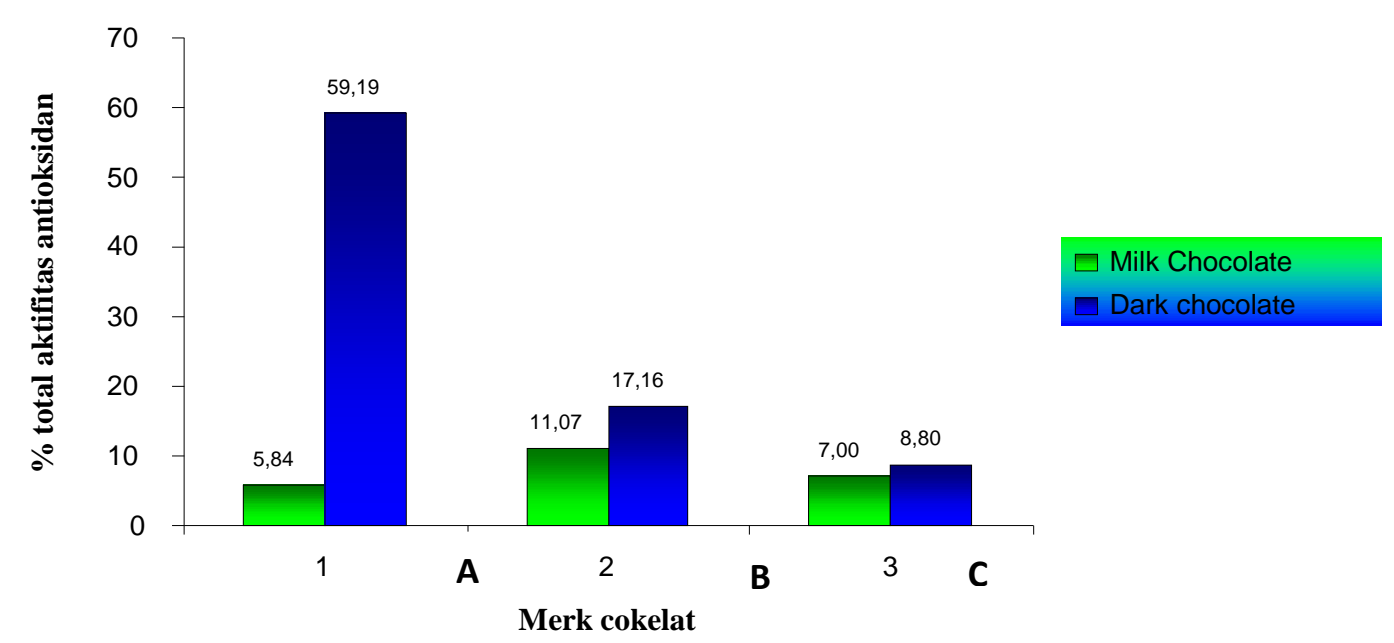

Gambar 4. Grafik perbandingan persentase total aktifitas antioksidan pada beberapa jenis dan merk cokelat

Radikal bebas dikenal sebagai faktor utama dalam kerusakan biologi, dan DPPH digunakan untuk mengevaluasi aktivitas peredaman radikal bebas dari suatu antioksidan alami. Elektron tak berpasangan pada DPPH memberikan suatu absorpsi yang kuat, maksimum pada $\lambda 517 \mathrm{~nm}$ dan berwarna ungu. DPPH merupakan senyawa radikal bebas stabil yang akan saling menetralkan, jika direaksikan dengan senyawaan antioksidan sebagai penangkap radikal bebas ini dengan adanya sebuah donor hidrogen. Antioksidan yang terkandung dalam sampel (senyawa x pada Gambar 5) menyebabkan elektron menjadi berpasangan yang kemudian menyebabkan penghilangan warna sebanding dengan elektron yang diambil, sehingga terdapat perbedaan besarnya nilai serapan (absorbans) dari masing-masing sampel. Perbedaan ini berbanding lurus dengan banyaknya kandungan antioksidan dalam sampel tersebut. Senyawa antioksidan dapat mengubah warna arutan DPPH dari ungu menjadi kuning (Dehpour etl al., 2009). Semakin banyak jumlah antioksidan dalam sampel maka akan semakin banyak juga penghilangan warna yang dihasilkan dari reaksi antara DPPH dengan sampel. Warna akhir yang diukur sebagai nilai serapan sampel merupakan warna dari sisa DPPH yang tidak bereaksi dengan antioksidan dalam sampel.

Sampel merk C, cokelat yang tidak terdapat madu, kacang almon maupun kacang mete di dalamnya sebagai bahan tambahan, sehingga aktifitas antioksidan yang diperoleh dari sampel merk $\mathrm{C}$ hanya berasal dari katekin dan antioksidan lain dalam cokelat itu sendiri (Gambar 1), menempati urutan ketiga dengan hasil persentase total aktifitas antioksidan pada dark chocolate sebesar $8.80 \%$. Sampel dark chocolate merk A memberikan rasa yang paling pahit jika dibandingkan dengan sampel dark chocolate merk B dan C. Hal ini menunjukkan bahwa komposisi cokelat terbesar terkandung dalam sampel dark chocolate merk A tersebut. Selain itu, warna pada sampel dark chocolate merk A paling gelap jika dibandingkan dengan warna pada sampel dark chocolate merk B dan $\mathrm{C}$.

Berbeda halnya dengan sampel milk chocolate, persentase total aktifitas antioksidan terbesar dihasilkan oleh sampel milk chocolate merk $\mathrm{B}$, sebesar $11.07 \%$, urutan kedua dihasilkan oleh sampel milk chocolate merk $\mathrm{C}$ sebesar $7.00 \%$ dan hasil terkecil pada sampel milk chocolate merk A sebesar $5.84 \%$. Hal ini terjadi karena perbedaan besarnya jumlah cokelat di dalam masing - masing sampel. Warna pada sampel milk chocolate merk B 
paling gelap jika dibandingkan dengan warna pada sampel milk chocolate merk $\mathrm{C}$, apalagi jika dibandingkan dengan sampel milk chocolate merk A yang terlihat paling pucat. Meskipun sampel milk chocolate merk A mengandung bahan tambahan yang sama dengan yang terdapat pada sampel dark chocolate merk A, tetapi kandungan cokelat di dalamnya sangat sedikit, dapat dilihat dari warnanya yang sangat pucat tersebut, sehingga semakin menguatkan bahwa jumlah katekin dan antioksidan lain yang terkandung dalam cokelat memberikan aktifitas antioksidan sesuai dengan besarnya jumlah kandungan zat tersebut di dalam masing - masing sampel cokelat.

Besarnya aktivitas antioksidan juga sangat dipengaruhi oleh jenis bahan tambahan yang terkandung dalam cokelat. Madu, kacang almon dan kacang mete sebagai bahan tambahan dalam cokelat ternyata memberikan aktifitas antioksidan juga. Sehingga aktifitas antioksidan dalam cokelat tidak hanya berasal dari katekin dan antioksidan lain dalam cokelat itu sendiri, tapi juga berasal dari bahan tambahannya. Sampel dark chocolate memberikan hasil persentase total aktifitas antioksidan lebih besar daripada yang dihasilkan oleh sampel milk chocolate pada masing - masing merk.

Menurut Eskin dan Przybylski (2001) dalam Sari (2005), mekanisme kerja senyawa antioksidan adalah mengkelat ion logam, menghilangkan oksigen radikal, memecah reaksi rantai inisiasi, menyerap energi oksigen singlet, mencegah pembentukan radikal, menghilangkan dan atau mengurangi jumlah oksigen yang ada. Mekanisme reaksi senyawa antioksidan sebagai berikut :

$\mathrm{AH}+\mathrm{ROO} . \square \mathrm{A} .+\mathrm{ROOH}$

$\mathrm{AH}+\mathrm{RO} . \square \mathrm{A} .+\mathrm{ROH}$

A. + ROO. $\square \mathrm{AOOH}$

A. + RO. $\square$ AOH

A. + A. $\square$ AA

A. $+\mathrm{O} 2 \square$ AOO.

A. $+\mathrm{RH} \square \mathrm{AH}+\mathrm{R}$.

Keterangan :

$\mathrm{AH}=$ antioksidan $\mathrm{ROO} .=$ radikal peroksil

$\mathrm{RH}=$ lemak atau minyak tak jenuh

R. = radikal asam lemak tak jenuh

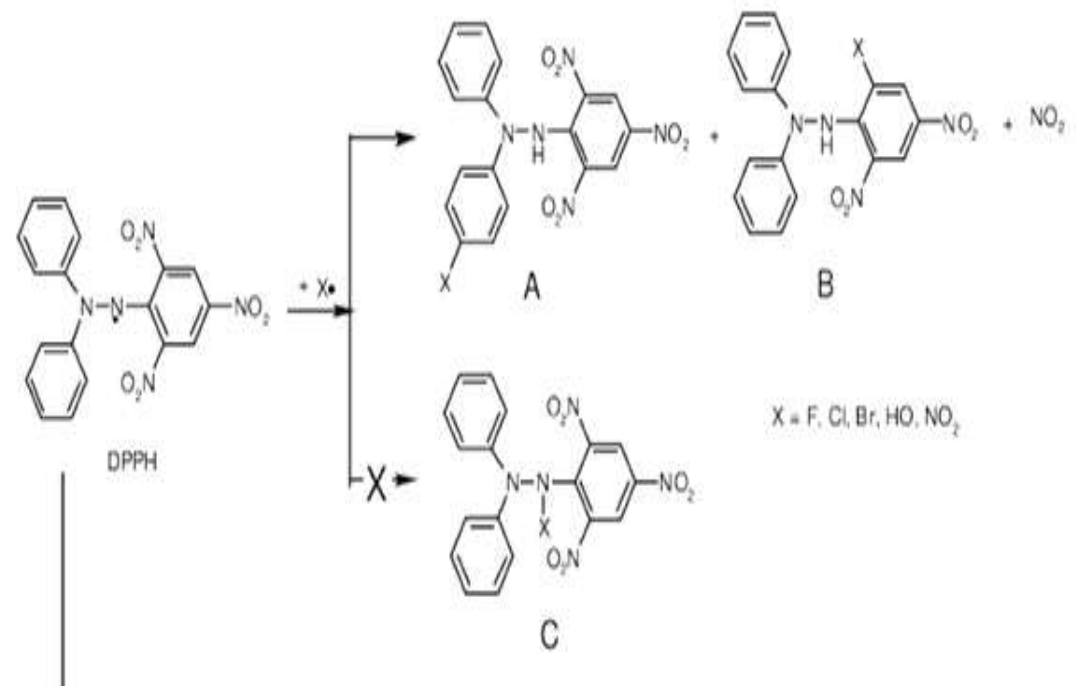

Gambar 5. Reaksi antara DPPH dengan senyawa x (katekin, riboflavin,vitamin E, vitamin $\mathrm{C}, \mathrm{Mg}$ dan $\mathrm{Cu}$ ) 


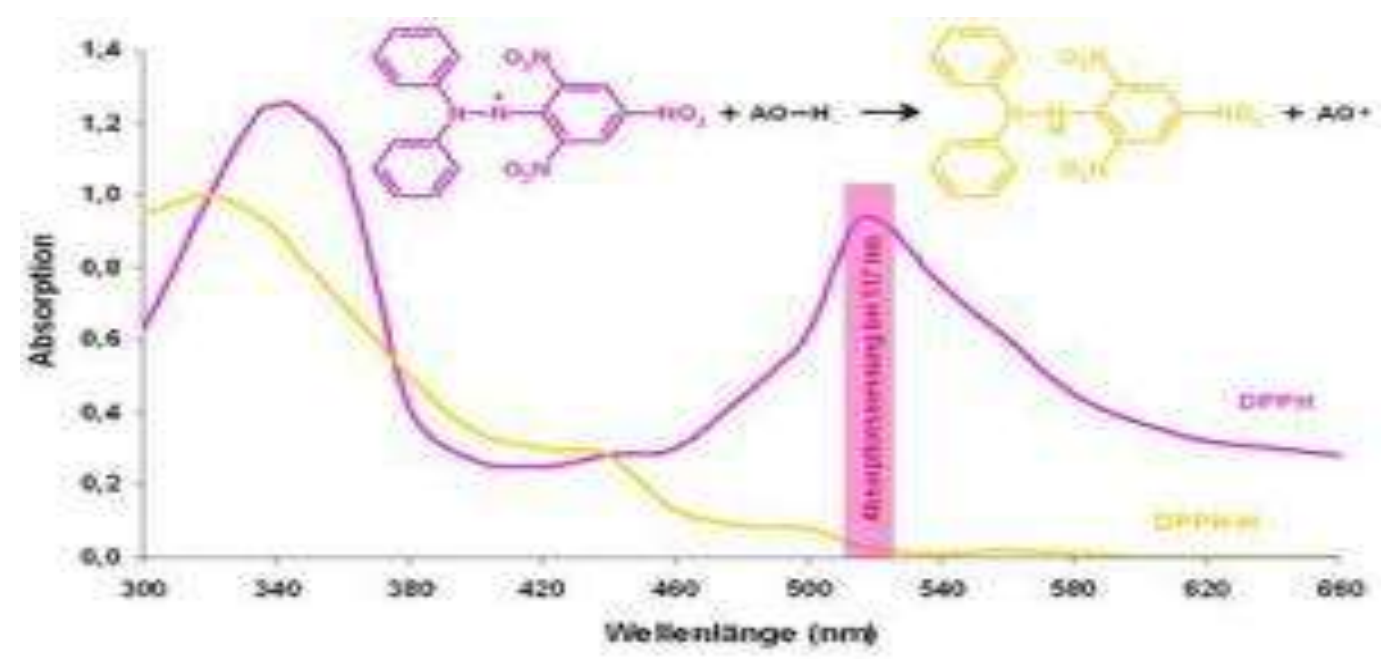

Gambar 6. Perubahan warna larutan pada reaksi radikal DPPH dengan antioksidan (Witt et al, 2010)

Menurut Hartanto (2012), hasil penelitian terhadap potensi antioksidan minuman cokelat menggunakan metode radikal bebas DPPH, menunjukkan bahwa minuman cokelat yang mengalami berbagai preparasi seperti penambahan air mendidih $\left(100 \quad{ }^{\circ} \mathrm{C}\right)$ langsung dan penambahan air suhu ruang kemudian dipanaskan sampai mendidih, menunjukkan aktivitas penangkalan radikal bebas DPPH tidak berbeda nyta dibanding dengan vitamin $\mathrm{E}$ sebagai kontrol pada taraf 5\%.

Asam askorbat sebagai pembanding pada penelitian ini, menghasilkan persentase total aktifitas antioksidan sebesar $45.13 \%$. Hal ini menunjukkan bahwa kandungan antioksidan dalam cokelat tidak kalah pentingnya dengan antioksidan yang terkandung dalam asam askorbat. Angka ini masih jauh lebih kecil jika dibandingkan dengan angka yang dihasilkan dari persentase total aktifitas antioksidan sampel dark chocolate merk A, yaitu sebesar $59.19 \%$.

Asam askorbat (vitamin C) mudah dioksidasi menjadi asam dehidroaskorbat, dengan demikian maka vitamin $\mathrm{C}$ juga berperan dalam menghambat reaksi oksidasi yang berlebihan dalam tubuh dengan cara bertindak sebagai antioksidan. Vitamin $\mathrm{C}$ terkandung dalam sayuran berwarna hijau dan buah - buahan (Sofia, 2005).

Selain vitamin $\mathrm{C}$, coklat memiliki senyawa polifenol yang berfungsi sebagai antioksidan dan pengawet alami dari coklat. Aktivitas antioksidan polifenol berkaitan erat dengan struktur samping dan substitusi pada cincin aromatiknya, serta jumlah dan posisi hidrogen fenolik dalam molekulnya. Dengan demikian, aktivitas antioksidan tinggi karena memiliki jumlah gugus hidroksi yang lebih banyak pada inti flavonoidnya (Es-Safi et al. 2007., dalam Yuhernita dan Juniarti, 2011). Senyawa fenolik ini memiliki kemampuan untuk menyumbangkan hidrogen, maka aktivitas antioksidan senyawa fenolik dapat dihasilkan pada reaksi netralisasi radikal bebas, yang mengawali proses oksidasi atau pada penghentian reaksi radikal berantai yang terjadi.

Hasil penelitian ini menambah informasi bahwa ternyata cokelat mengandung banyak antioksidan yang dapat disejajarkan dengan bahan makanan sehat lain yang merupakan sumber utama antioksidan, salah satunya yaitu makanan yang banyak mengandung vitamin $\mathrm{C}$. Sehingga cokelat (dark chocolate merk A khususnya) dapat dijadikan sebagai sumber antioksidan. 


\section{DAFTAR PUSTAKA}

Afriansyah, N. 2005. Cokelat, Sarat Antioksidan Penyehat Jantung. http://www2. kompas.com/kompascetak/0503/30/ilpeng/1652470. htm.(Rabu, 30 Maret 2005)

Amrun, M. 2005. Pengujian Antiradikal Bebas Difenilpikril Hidrazil (DPPH) Ekstrak Buah Kenitu (Chrysophyllum cainito,L.) Dari Daerah Sekitar Jember.Jurnal Ilmu Dasar Vol. 6. No. 2, $2005: 110$ - 114.

Anonim, 2008. Antioksidan Tinggi dalam Coklat Hitam. http://www. qvida.co.id/ index. php/news/detil/145.(17 Oct 2008).

Anonim, 2009. Coklat Membuat Hidup Lebih Sehat. http://kumpulan.info /sehat/ artikel-kesehatan/48-artikelkesehatan/161-cokelatmembuat-hidup-lebih sehat.html(Selasa, 17 Maret 2009)

Anonim, (Tanpa Tahun). Antioksidan. http://id.wikipedia.org/wiki/Ant ioksidan

Astawan, M. 2009. Cokelat, Tanda Sayang Sehatkan Jantung. http://perempuan. kompas.com/read/xml/2009/02/ 12/22155938/cokelat.tak.selam anya.merugikan. (Nutrition Thu, 26 Feb 2009 15:30:00 WIB)

Brotodjojo, LC. 2008. All About Chocolate.Jakarta:

PT.Gramedia Pustaka Utama.

Dehpour, A. A., M. A. Ebrahimzadeh, , N. S. Fazel, dan N. S. Mohammad, 2009. Antioxidant Activity of Methanol Extract of Ferula assafoetida and Its Essential
Oil Compotition., Grass Aceites, 60 (4), $405-412$.

Hartanto, H. 2012. Identifikasi potensi antioksidan minuman cokelat dari kakao lindak (Theobroma cacao L.) dengan berbagai cara preparasi metode radikal bebas 1,1 diphenyl-2 picryhidrazil (DPPH). Skripsi. Fak.Teknologi Pertanian. Univ. Katolik Widya Mandala. Surabaya.

Joseph, JA., 2008. Diet Sehat Dengan Kode Warna Makanan. PT. Mizan Publika : Jakarta.

Kuncahyo, I., 2007. Uji Aktifitas Antioksidan Ekstrak Belimbing Wuluh (Averrhoa bilimbi,L.) terhadap 1,1-Diphenyl-2Picrylhydrazyl (DPPH). Makalah pada Seminar Nasional Teknologi (SNT 2007) : Yogyakarta.

Liempah, MVL., 2008. Production Of Bee-Propolis Extract Powder As Antibacterial Material For Pharmaceutical Industry. Swiss German University : Tangerang.

Nur, MA. 1989. Spektroskopi. Institut Pertanian Bogor : Bogor.

Rusdiana, T. 2007. Formulasi Gel Antioksidan Dari Ekstrak Seledri (Apium graveolens,L.) Dengan Menggunakan AQUPEC HV-505. Makalah pada Kongres Ilmiah XV ISFI : Jakarta.

Sari, D., 2009. Aktivitas Antioksidan Daun Belantas dalam Sistem Model Asam Linoleat Beta Karoten. Skripsi S-1. Surabaya : Fakultas Teknologi Pertanian, Universitas Katolik Widya Mandala Surabaya. 
Sofia, D., 2005. Antioksidan dan Radikal Bebas. Situs Web Kimia (online). http:www.chemistry.org.(diakses Maret 2009).

Tahir, I. 2003. Terapan Analisis HANSCH Untuk Aktifitas Antioksidan Senyawa Turunan Flavon / Flavonol. Makalah Seminar Khemometri. 25 Januari 2003. Jurusan Kimia FMIPA UGM : Yogyakarta.

Tim Bina Karya Tani., 2008. Pedoman Bertanam Cokelat. Yrama Widya : Bandung.
Witt, S., M. Lalk, C. Hager dan B. Voigt, 2010. Determination of Scavenger properties, http://www.balticanalytics./index. php?id=7\&L-1, diakses tanggal 14 September 2010 .

Yuhernita dan Juniarti. 2011. Analisis Senyawa Metabolit Sekunder dari Ekstrak Metanol Daun Surian yang Berpotensi sebagai Antioksidan. Makara, Sains. Vol. 15, No. 1, April 2011 : 4852 . 